Фроленкова Н. А., к.е.н., доцент (Національний університет водного господарства та природокористування, м. Рівне)

\title{
ОСВІТА І ПРОФЕСІЙНИЙ РОЗВИТОК ПЕРСОНАЛУ ЯК ЕЛЕМЕНТ КАДРОВОГО МЕНЕДЖМЕНТУ ОРГАНІЗАЦІЙ
}

У статті визначені основні проблеми кадрового менеджменту сучасних організацій, сформульовані завдання та шляхи підвищення ефективності систем управління персоналом. Визначені необхідні елементи сучасного кадрового менеджменту. Детально охарактеризовані особливості і перспективи впровадження дорослої освіти як компонента системи підвищення конкурентоздатності працівників в організаціях. Сформульовані основні складові дуальної освіти, їі необхідність та значення в умовах формування фахівця, який відповідає потребам ринку i часу.

Ключові слова: кадровий менеджмент; управління персоналом; освіта впродовж життя; доросла освіта; дуальна освіта; конкурентоспроможність персоналу.

Постановка проблеми. Епоха інформаційної цивілізації характеризується новою системою цінностей, де статус людини і суспільства буде визначати не стільки кількість накопичених матеріальних благ, а рівень культури, освіти, розумного господарювання, що забезпечує збереження і відтворення ресурсів. Якщо раніше основну роль у розвитку держав і націй відігравали природні ресурси і фінанси, то сьогодні основним багатством $\epsilon$ «людський капітал». Тобто, конкурентоспроможність та стабільність роботи організацій в сучасних умовах залежить від ряду факторів, одним 3 визначальних серед яких $€$ рівень компетенції та професіоналізму персоналу. Людський ресурс сьогодні вважається найважливішим стратегічним ресурсом будь-якої компанії, а відтак кадровий менеджмент і його складові - надзвичайно важливим елементом сучасної системи менеджменту.

За оцінками роботодавців, основними проблемами в системі сучасного кадрового менеджменту на підприємствах є:

- низький рівень теоретичної та практичної підготовки потенційних працівників;

- відсутність бажання і професійних якостей у багатьох випускників ЗВО працювати за спеціальністю; 
- необхідність додаткового навчання та стажування молодих працівників на робочих місцях;

- обмежений вибір на ринку праці регіону;

- відсутність в організаціях комплексних ефективних механізмів оцінювання відповідності працівників робочим місцям;

- відсутність у переважної частини кадрового складу так званих Soft skills (сучасне економічне і стратегічне мислення, навики спілкування та комунікацій, аргументації і логічного мислення, емоційна компетентність, лідерські якості, самоменеджмент та інше);

- відсутність у працівників бачення свого місця в організації в перспективі, прагнення до професійного розвитку та удосконалення;

- старіння та втрата актуальності знань, умінь та навичок працівників компаній.

Усунути вищезазначені недоліки та підвищити ефективність і конкурентоздатність персоналу допоможе впровадження в компаніях систем професійного розвитку працівників, яка являє собою механізм безперервного набуття нових компетенцій, знань, умінь і навиків, які вони використовують чи будуть використовувати у своїй професійній діяльності. У більш вузькому розумінні така система розглядається як процес підготовки, перепідготовки й підвищення кваліфікації працівників з метою виконання нових виробничих функцій, завдань і обов'язків нових посад.

Невирішена раніше частина загальної проблеми. Професійний розвиток персоналу в організаціях сьогодні повинен бути безперервним комплексним процесом, який включає: професійне навчання, розвиток кар'єри та підвищення кваліфікації. Реалізація концепції розвитку персоналу передбачає створення гнучкої, конкретної системи професійного навчання, зорієнтованої на вирішення стратегічних завдань організації.

Проте традиційно протягом багатьох десятків років вітчизняні керівники підприємств і організацій надають другорядну роль людському чинникові в бізнесі, підпорядковану фінансовим і виробничим завданням. В Україні склалась ситуація, коли управлінню персоналом не приділяється достатньо уваги, технологія розробки і прийняття кадрових рішень є недосконалою і науково необґрунтованою, у більшості випадків відсутня орієнтація на досягнення соціальної ефективності. Служби управління персоналом у підприємствах мають, як правило, низький організаційний статус i розглядаються як допоміжний, обслуговуючий підрозділ з вузьким спектром виконуваних функцій [1]. 
В межах системи розвитку персоналу в сучасних організаціях необхідно передбачити наступні завдання:

- швидка адаптація нового персоналу на робочому місці;

- доведення рівня професійності молодих працівників до необхідного кваліфікаційного рівня;

- забезпечення відповідності персоналу вимогам робочих місць;

- формування у керівників структурних підрозділів управлінського стратегічного мислення;

- формування соціальних навичок (Soft Skills) у працівників всіх рівнів;

- розробка і впровадження механізму «управління кар'єрою» для працівників підприємства;

- забезпечення персоналу сприятливих умов для неформального навчання та самоосвіти;

- систематизація і планування процесу професійнокваліфікаційного просування працівників.

Цілі дослідження. Вищеперераховані завдання можуть бути вирішені шляхом побудови механізму професійного росту і розвитку персоналу, який повинен включати наступні компоненти:

1. Впровадження системи навчання нових працівників на робочому місці - наставництво.

2. Впровадження механізму навчання персоналу, особливо керівного складу, основам сучасного менеджменту, професійнопсихологічної підготовки, соціальним навичкам.

3. Формування комплексних стратегічних та оперативних планів підвищення кваліфікації та перепрофілювання працівників.

4. Підбір, формування та навчання кадрового резерву.

5. Заохочення та розробка системи «дорослої освіти».

6. Приєднання до державної програми дуальної освіти.

Якщо перші чотири елементи, так чи інакше, є традиційними для великих і середніх організацій, то системи дорослої та дуальної освіти для вітчизняних підприємств є новинками. Розглянемо ці елементи кадрового менеджменту, можливість, особливості та перспективність їх реалізації в Україні.

Основні результати дослідження. В соціальному плані нинішня система національної освіти, відірвана від реальних потреб економіки, працює не на розвиток особистості і суспільства, а на їх стагнацію. Нині нова роль інформації і знань зробили реальною «освіту без кордонів», змінили форми і методи організації навчання в різних інститутах системи освіти, посилили значення ринкових 
механізмів, що призведе до появи міжнародного ринку людського капіталу.

Основним завданням системи підготовки людини до продуктивного життя і праці в сучасному світі стає не стільки надання інформації, скільки навчання способам їі отримання та використання. Іншими словами, навчальні заклади сьогодні покликані надавати свої послуги не у вигляді навчання конкретному знанню, а у вигляді передачі технології отримання і застосування знань. Рух освітнього процесу в даному напрямку здатний надати новий імпульс соціальному розвитку суспільства, однак така парадигма передбачає новий підхід до суб'єктів системи освіти.

Майбутня перспективна система освіти потребує докорінного перегляду більшості наших уявлень про традиційні освітні практики. Однією $з$ тенденцій майбутньої освітньої парадигми є створення ефективної системи безперервної освіти людини протягом всього його життя. Принцип безперервності освіти передбачає виховання людини нового типу, яка в динамічно мінливих соціальноекономічних умовах зможе активно жити і діяти, вносити максимальний вклад в саморозвиток і самореалізацію, в розвиток суспільства, його прогресивне оновлення. Розвиток особистості розглядається при цьому як безперервний процес, який орієнтує навчально-пізнавальну діяльність не тільки на засвоєння знань, а й на активне перетворення навколишнього світу. Завдання безперервної освіти полягає не тільки в збагаченні людини новими знаннями, але і в збереженні її професійної компетентності протягом усього життя.

На фоні швидких і різноспрямованих змін зростає роль знань, умінь і навичок усіх членів суспільства. Економічно розвинуті країни інтенсивно розвивають і удосконалюють систему освіти дорослих як елементу освіти впродовж життя, що забезпечує успішний розвиток суспільства. Збільшення середньої тривалості освіти дорослого населення всього лише на один рік в довгостроковому плані веде до збільшення економічного зростання на 3,7\% і до підвищення доходів на душу населення на 6\% [2].

Людський ресурс, як будь-який інший ресурс, має свою цінність на ринку. Освіта, нові знання і компетенції підвищують цінність людини на ринку праці, що призводить доросле населення до розуміння необхідності підвищення рівня знань 3 метою самореалізації та конкурентоспроможності.

Через швидку глобалізацію та інформатизацію суспільства відбувається прискорений процес морального і фактичного 
знецінення та старіння знань і умінь фахівців. Сьогодні спостерігається величезний розрив між знаннями і навичками, набутими фахівцем 10-15 років тому, і тими вимогами, які пред'являє до нього суспільство в результаті впровадження нових технологій, соціально-економічних трансформацій. Настає момент, коли фахівець високої кваліфікації стає непридатним для подальшої роботи, тому перенавчання, постійного підвищення професійної компетентності, участі в системі додаткової освіти та перепідготовки періодично потребують фахівці всіх вікових категорій. Це сприяє скороченню розриву в освіті представників різних поколінь, а також зростанню конкурентоспроможності компанії на ринку. Дослідження, проведене в ряді американських компаній, показало, що збільшення на $10 \%$ витрат на навчання персоналу дає приріст продуктивності праці на 8,5\%, тоді як таке ж збільшення капіталовкладень підвищує продуктивність праці лише на 3,8\%. Компанія (і співробітники) буде процвітати доти, поки темп навчання в ній буде вищий (або дорівнюватиме) темпу зміни зовнішнього середовища [2].

Крім того, щорічно в світовому господарстві відмирає понад 500 старих професій і виникає приблизно стільки ж нових. Об'єктивна потреба постійно освоювати нові технології, нестримно нав'язувані нам науково-технічним прогресом. Технічний прогрес ставить дорослого перед необхідністю позбутися «старого» досвіду заради придбання нового. Досвід, як життєвий, так і професійний часто стає перешкодою для професійного зростання, якщо він не відповідає сучасним вимогам.

Згідно зі сформованою в міжнародному освітньому співтоваристві практикою прийнято виділяти три види освітньої діяльності, які відносяться і до навчання дорослих:

1. Формальна освіта, що завершується видачею загальновизнаного диплома або атестата. Формальне освіта не здатна так швидко реагувати на потреби ринку праці.

2. Неформальна освіта, як правило, не супроводжується видачею документа. Відбувається в освітніх установах або громадських організаціях, клубах і гуртках, а також під час індивідуальних занять 3 репетитором або тренером. Саме неформальна, неінституалізована освіта - більш гнучка, воно дає людині право вибору - де, коли, в якому обсязі і яким чином отримувати необхідні знання. Це можуть бути курси, лекції, тренінги та інше. Тому неформальна освіта дорослих набуло в світі такий розвиток. Якщо людина знатиме, що результати його навчання позаформальної системи освіти можуть бути враховані і визнані, 
з'являється мотивація для професійного розвитку з використанням неформального та інформального навчання.

3. Інформальна (спонтанна) освіта - індивідуальна пізнавальна діяльність, що супроводжує повсякденне життя і не обов'язково носить цілеспрямований характер.

Отже, впровадження комплексного механізму безперервної освіти в будь-якій організації, з урахуванням специфіки галузі, якісного складу персоналу, актуальних вимог часу і ринку, гарантовано підвищить стабільність і процвітання підприємства, забезпечуючи йому чималі конкурентні переваги.

Що стосується запровадження такої форми навчання студентів, як дуальна освіта, то така специфічна форма навчання виникла як відповідь на необхідність поглибити практичну підготовку майбутніх фахівців під час їх навчання у ЗВО. Наша країна володіє унікальною рисою: при високій питомій вазі працівників 3 вищою освітою (4 місце в світі), наші випускники знаходяться на 94 місці за якістю підготовки в компаніях та організаціях. Тривалий час зберігається тенденція, коли наявність диплому не $€$ підтвердженням високого рівня фахівця, а скоріше елементом бюрократичної вітчизняної системи.

Вищезазначений вид освіти дає можливість студентові поєднувати навчання у закладі освіти з навчанням на конкретних посадах на підприємствах, в установах, організаціях для набуття практичного досвіду, глибшого розуміння теоретичного матеріалу та одержання певної кваліфікації. Дуальна форма навчання передбачає узгоджену та закріплену договірними відносинами взаємодію освітньої та виробничої сфери з метою підготовки кваліфікованих кадрів. При цьому організації, які беруть участь в подібній програмі, визначають перелік необхідних їй спеціальностей й замовляють навчальному закладу.

Необхідність і доцільність впровадження такої форми навчання в Україні зумовлені наступними причинами.

По-перше, спостерігається значний розрив між теорією, яку вивчають у ЗВО і реальною практикою. Особливо це стосується сучасних сфер і спеціальностей, де знання застарівають надзвичайно швидко, наприклад IT-спеціальностей, маркетологів, менеджерів, бухгалтерів і фінансистів, деяких інженерних спеціальностей. Студенти роками вивчають дисципліни та інструменти, які вже не відповідають сучасним потребам бізнесу і вимогам роботодавців, часу і ринку праці. 
По-друге, така форма навчання, як навчальна чи виробнича практика в багатьох закладах вищої освіти перетворилась на формальність. Впровадження дуальної освіти дозволить перевести таку формалізовану практику в реальну корисну форму навчання.

Дуальна форма навчання $\epsilon$ цікавою і корисною і для роботодавців. За оцінками фахівців, частина підприємств в Україні вже готові піти на експеримент і навіть фінансувати частину видатків на підготовку таких спеціалістів. Але, така співпраця освіти і виробництва потребує відповідного законодавчого забезпечення, врегулювання договірних та фінансових відносин. Бізнес потребує стимулів, додаткових пільг i гарантій на державному i законодавчому рівні. Наприклад, можливості віднесення витрат на підготовку студентів на собівартість продукції, закріплення за студентом певних зобов'язань перед компанією. Наразі елементи дуальної освіти активно впроваджують філії іноземних, переважно німецьких, компаній. А у вітчизняних організаціях банально не вистачає вільних коштів, аби інвестувати їх в освіту, особливо в умовах масового відтоку людського капіталу за кордон [4].

Найважливішим елементом дуальної форми освіти $є$ роль роботодавця в освітньому процесі, який відіграє не меншу роль, ніж викладач навчального закладу. Він перестає бути споживачем кінцевого продукту, а стає активним учасником його підготовки і має можливість впливати на формування професійних навичок майбутнього працівника, готуючи його «під себе». Куратори студентів від підприємства повинні брати участь в складанні індивідуальних планів навчання студентів, графіків індивідуальних занять; програм стажування на підприємстві, брати участь в проведенні заліків, іспитів, захисту кваліфікаційних робіт.

Висновок. Таким чином, стабільність роботи і конкурентоспроможність сучасних підприємств і організацій значною мірою залежать від якості i конкурентоздатності їх персоналу. Підвищити ефективність роботи персоналу можна шляхом розробки і впровадження прогресивної системи кадрового менеджменту. Одним з сучасних елементів таких систем $€$ освіта дорослих, що дозволяє вчасно реагувати на зміни потреб ринку, підвищити цінність людини на ринку праці, впровадити в діяльність підприємства нові інноваційні технології. Новою для нашої країни $є$ дуальна освіта, яка дозволяє роботодавцю за певних умов отримати фахівця високого рівня з необхідними підприємству навичками і знаннями.

1. Балабанова Л. В., Сардак О. В. Управління персоналом : підручник. К. : Центр 
учбової літератури, 2011. 468 с. 2. Галичин В. А. Основные характеристики и тенденции развития образования взрослых в условиях глобализации. Век глобализации. Вып. №1(9)/2012. С. 104-114. 3. Мальцев К. Особенности обучения взрослых: аксиомы обучения и развития сотрудников. ULR: https://www.cfin.ru/management/people/dev_val/adult_education.shtml (дата звернення: 10.02.2020). 4. Скиба М. Дуальна освіта: як пересадити німецький досвід на український ґрунт? ULR: https://blog.liga.net/user/mskyba/article/33178/ (дата звернення: 10.02.2020).

\section{REFERENCES:}

1. Balabanova L. V., Sardak 0. V. Upravlinnia personalom : pidruchnyk. K. : Tsentr uchbovoi literatury, 2011. 468 s. 2. Halichin V. A. Osnovnye kharakteristiki i tendentsii razvitiia obrazovaniia vzroslykh $\mathbf{v}$ usloviiakh hlobalizatsii. Vek hlobalyzatsii. Vыp. №1(9)/2012. S. 104-114. 3. Maltsev K. Osobennosti obucheniia vzroslykh: aksiomy obucheniia i razvitiia sotrudnikov. ULR: https://www.cfin.ru/management/people/dev_val/adult_education.shtml (data zvernennia: 10.02.2020). 4. Skyba M. Dualna osvita: yak peresadyty nimetskyi dosvid na ukrainskyi grunt? ULR: https://blog.liga.net/user/mskyba/article/33178/ (data zvernennia: 10.02.2020).

Frolenkova N. A., Candidate of Economics (Ph.D.), Associate Professor (National University of Water and Environmental Engineering, Rivne)

\section{EDUCATION AND PROFESSIONAL DEVELOPMENT OF PERSONNEL AS AN ELEMENT OF HR-MANAGEMENT}

The article is devoted to improving the efficiency of personnel management at enterprises. The main problems of personnel management of modern organizations are identified, the tasks and ways of increasing the efficiency of personnel management systems are formulated. Today it is: low level of training of potential employees; the need for additional training and internships for young workers in the workplace; absence of the overwhelming majority of Soft skills; employees lack of vision of their place in the organization in the future; aging and losing the knowledge, skills and skills of companies. The implementation of professional development systems in companies will help to eliminate the shortcomings and increase the efficiency and competitiveness of the personnel. It is a mechanism for the continuous acquisition of new competences, knowledge, skills and competencies by employees that they use or will use in their professional activities. The author has formulated the necessary elements of modern personnel management in Ukraine. The mechanism of professional growth and development of personnel should include the following components: training of new employees in the workplace, mentoring; management training of the basics of modern management, social skills; development of 
comprehensive strategic and operational plans for upgrading skills and reprofiling of employees; selection and training of personnel reserve; promoting and developing an adult education system; joining the state dual education program. Features and prospects of introduction of adult education as an element of increase of competitiveness of workers in the organizations are investigated. The main components of dual education, its necessity and importance in terms of forming a specialist, which meets the needs of the market and time are formulated.

Keywords: personnel management; HR-management; lifelong learning; adult education; dual education; personnel competitiveness.

Фроленкова Н. А., к.э.н., доцент

(Национальный университет водного хозяйства и природопользования,

г. Ровно)

\section{ОБРАЗОВАНИЕ И ПРОФЕССИОНАЛЬНОЕ РАЗВИТИЕ ПЕРСОНАЛА КАК ЭЛЕМЕНТ КАДРОВОГО МЕНЕДЖМЕНТА ОРГАНИЗАЦИЙ}

В статье определены основные проблемы кадрового менеджмента современных организаций, сформулированы задачи и пути повышения эффективности систем управления персоналом. Определены необходимые элементы современного кадрового менеджмента. Подробно охарактеризованы особенности и перспективы внедрения образования взрослых как компонента системы повышения конкурентоспособности персонала в организациях. Сформулированы основные составляющие дуального образования, его необходимость и значение в условиях формирования специалиста, который отвечает потребностям рынка и времени.

Ключевые слова: кадровый менеджмент; управление персоналом; образование в течение жизни; образование взрослых; дуальное образование; конкурентоспособность персонала. 